\title{
Online Entrepreneurial Behavior and Its Influencing Factors
}

\author{
Jiani Dong ${ }^{1, a}$, Weilun Huang ${ }^{1, b,{ }^{*}}$ \\ ${ }^{1}$ School of Finance, Wenzhou Business College, China \\ a592912298@qq.com, bhuangwl@wzbc.edu.cn \\ ${ }^{\star}$ Corresponding author
}

Keywords: Online Entrepreneurial Behavior; Online Entrepreneurship; Influence Factors

\begin{abstract}
The purpose of this paper is to analyze online entrepreneurial behavior and its influencing factors by conducting a questionnaire survey in China. The empirical results of Chinese respondents are that their average monthly cost in online entrepreneurship is RMB 9,125, and their average monthly revenue is RMB 18,596.15. And the cognitions on the convenience of online entrepreneurial platform, the development of online entrepreneurship, the social relationship of online entrepreneurship, the advantage of online entrepreneurship and personal variables are mostly and significantly influencing factors of online entrepreneurial behavior. This paper suggests that the government's policies on online entrepreneurship should be differentiated according to individual characters of online entrepreneur and improved the services of online entrepreneurial platform.
\end{abstract}

\section{Introduction}

Nowadays, online entrepreneurship has become a way for Chinese people to found new businesses or second job. Many countries also issue policies or distribute subsidies to encourage people to start online entrepreneurship. However, there are still few documents discussing people's online entrepreneurial behavior, so the purpose of this paper is to use literature review and questionnaire analysis to understand the Chinese people's online entrepreneurial behavior and its influencing factors, and then provide government, business and scholars some related policies and advice on research topics. Netease Cloud and ITJUZI (2017) found that the number of Chinese online entrepreneurship increased by 3,248 in September 2017. In the first half of 2017, the amount of venture capital was RMB 405.3 billion, and the number of investment cases was 3,228. The average financing amount growth rate of a single case was 40\%. Most of the start-ups (62\%) are located in Beijing, Shanghai and Guangzhou. The policy focus of Guangdong Province (2015) was to gradually popularize Internet applications in various fields of the economy and society, such as e-commerce, cloud computing, Internet of Things, big data and other network entrepreneurial innovation systems. $\mathrm{Qu}$, et al. (2015) deemed that online entrepreneurial behavior is divided into exploration behavior and development behavior.

For example, Malaysia launched the Digital Free Trade Zone in 2017 to support SMEs and innovative companies in cross-border trade through its e-commerce market. And also India uses the Startup India initiative to provide guidance, training and entrepreneurship promotion for the life cycle of start-ups. The agreement began in January 2016 and has successfully nurtured multiple entrepreneurs (online entrepreneurship is the main entrepreneurial category), such as four weeks of free online learning courses, the establishment of academia and industry networks, research parks, incubators and the creation of new bases, etc. (Australian APEC Study Centre, 2017) Thailand utilizes the National ICT Master Plan to promote the development of SMEs in the network, such as micro-finance, legal policies, and technical services. (Ministry of Information and Communication Technology, 2005).

According to the literature, online entrepreneurship should be an important research topic, but there are still few documents discussing the success factors and financial support of online entrepreneurship. This paper sorts out the existing literature in China and finds that there are 430 articles on online entrepreneurship (in the title of the article) and 170 articles on Internet 
entrepreneurship (in the title of the article). The literature on Internet entrepreneurship (in the title of the article) began in 2000 and the most in 2017 (29 articles). Their research field is broad, mainly focusing on enterprise management, college students' entrepreneurship, entrepreneurship education, and financial management.

This paper defines the online entrepreneurial behavior according to the literature refers to the monthly operating cost and monthly operating revenue of the entrepreneur in the online entrepreneurial platform. For example, Zhang, et al. (2012) explore entrepreneurial performance based on entrepreneurial cost and revenue, and defined the influencing factors of online entrepreneurial behavior as the cognitions on development, advantage, social of online entrepreneurship and the convenience of online entrepreneurial platform.

The developmental cognitions of online entrepreneurship should be divided into competitive advantage, business continuity, development sustainability, and revenue growth. He (2011) believes that the competitive advantages of online entrepreneurship are its low cost, convenient service, and easy management of employees. Or, such as Zhou and Zhang (2017) deem that the competitive advantages of online entrepreneurship are low cost, flexible operation, variety, low risk, and unlimited time and distance. For another example, Zhou and $\mathrm{Wu}$ (2011) believe that the transformation of business models and consumption habits makes online entrepreneurship sustainable. Moreover, China E-Commerce Research Center (2012) found that China's personal online store rose from 7.6 million in 2008 to 11.24 million in 2013 (expected). For another example, Liu and Xing (2014) believe that online entrepreneurship has the potential for sustainable development due to the development of networks and e-commerce. As the scale of online shopping in China has risen to RMB 13.35 trillion in 2017 (China E-Commerce Research Center, 2017). Therefore, Qiu (2014) believes that the development of online entrepreneurship is based on business continuity, and believes that the threshold and cost of online entrepreneurship are low and online entrepreneurship can response fast and has unlimited trading areas, etc. Baum (2012) explores the size and revenue growth of new ventures.

The cognitions on advantages of online entrepreneurship should be divided into freedom of time and space, high cost-benefit and capacity improvement. For example, Xiao and Chen (2013) believe that online entrepreneurs are widely used due to the widespread use of network technologies such as Internet of Things, cloud computing, and cloud services, regardless of time, location, or region. As Zhang and Ma (2013) think that online entrepreneurs only need to master the source of the product and the basic operation skills of the online store, they can be free from time constraints. For example, $\mathrm{Hu}$, et al. (2010) believe that small-capital entrepreneurs are suitable for online entrepreneurship with low investment and high return. Qu, et al. (2015) believe that online entrepreneurs can increase their resource integration capabilities.

The convenience of online entrepreneurial platform should be divided into information richness, resource richness and numerous users. For example, Tian, et al. (2013) believe that online entrepreneurial platforms are based on local characteristics, brand sharing, data interconnection, and information exchange. Or, such as Yang (2013) thinks that the online entrepreneurial platform can provide relevant information from government departments such as customer supplier taxation. As the China Internet Information Center (2018) found that Chinese online users reached 802 million in 2018 (the penetration rate is $57.7 \%$ ). The social of online entrepreneurship should be divided into entrepreneurial associations, lecture training, successful people, relatives and friends. For example, Tian, et al. (2013) believe that the government should provide entrepreneurial training seminars for online entrepreneurs. And as Pan (2015) believes that expert forum lectures, schools and social entrepreneurship communities are helpful to online entrepreneurs. Su (2009) found that the school has invited successful entrepreneurs and related experts to assist online entrepreneurs. Qu (2015) believes that online entrepreneurs will discuss entrepreneurial effectiveness and problems with friends and family.

According to the above discussion, in addition to understanding the success factors of online entrepreneurship and financial support, this paper also discusses the impact by the gender, age, major, entrepreneurial time, and used online entrepreneurial platform of entrepreneur on the 
above-mentioned influencing factors. For example, Chen, et al. (2011) found that there are more male entrepreneurs than females, and the majority of online entrepreneurs are majored in economics and management. This paper also explore the impact of online entrepreneurial platform on performance. The main online entrepreneurial platform is Taobao. Chen, et al (2015) found that network entrepreneurs are the most ages 31 to 40 years old, and explore the relationship between network entrepreneurs' operating time and business performance.

In addition to the introduction, the article structure is divided into three parts, the second part is the analysis of questionnaire results, and the third part is the conclusion and suggestion.

\section{The Analysis of Questionnaire Survey}

The online questionnaire was conducted in China from September 27 to October 2, 2018. The number of valid copies was 520. The respondents were all web entrepreneurs. The statistics of personal variables were: 1. Gender: Men account for $49.8 \%$ and women account for $50.2 \%$. 2. Age: Respondents accounted for $16.7 \%$ of those under 22 years old, and $83.3 \%$ of those over 23 years old. 3. Startup-period time: The average time is 2.33 years, and the standard deviation is 1.224 years. 4 . Major: The management category accounts for $8.8 \%$, and the non-management category accounts for 91.15\%.5. Used online entrepreneurial platform (the usage ratio is ranked from high to low): Taobao accounts for $80 \%$, Paipai accounts for $7.1 \%$, others account for $4.4 \%$, eBay accounts for $4.2 \%$, and self-built websites account for $3.8 \%$.

The descriptive statistics of online entrepreneurial behavior variables are: the average monthly cost is RMB9125 (standard deviation is 4482.22), and the monthly revenue is RMB18596.15 (standard deviation is 12186.35). The average monthly cost of online entrepreneurship only considers the purchase cost and does not consider the operating cost.

The descriptive statistics of the influencing factors of online entrepreneurial behavior are: about three-quarters of the respondents approve that the influencing factors of online entrepreneurial behavior (the proportion of approvals are arranged from high to low) are the cognitions on the convenience of online entrepreneurial platform, the development of online entrepreneurship, the social of online entrepreneurship, and the advantages of online entrepreneurship. For example, $79.90 \%$ of respondents most approve with the freedom of time and space on the cognitions of the advantages of online entrepreneurship; $97.00 \%$ of the respondents most approve with the resource richness of the cognitions of the online entrepreneurial platform convenience; $92.50 \%$ of the respondents most approve with the developmental sustainability on the cognitions of the development of online entrepreneurship. $87.90 \%$ of respondents most approve with successful people who are socially influential in online entrepreneurship.

This paper summarizes the analysis results of the influencing factors of online entrepreneurial behavior on the online entrepreneurial behavior as shown in Table 1. It can be seen from Table 1 that the significant factors of online entrepreneurial behavior are the cognitions on the advantages, development, and social of online entrepreneurship, the conveniences of online entrepreneurial platform. The positive and significant influencing factors of online entrepreneurship cost are the cognitions on the convenience of online entrepreneurial platform, the development and social of online entrepreneurship. The positive and significant influencing factors of online entrepreneurship cost are the cognitions on the advantages of online entrepreneurship. 
Table 1 Analysis of the variation of influencing factors of online entrepreneurial behavior on online entrepreneurial behavior

\begin{tabular}{|l|l|l|l|}
\hline \multicolumn{2}{|l|}{} & \multicolumn{2}{l|}{ Online entrepreneurial behavior } \\
\cline { 3 - 4 } & $\begin{array}{l}\text { The cognitions of advantages of online } \\
\text { entrepreneurship }\end{array}$ & $53.73^{* * *}$ & Revenue \\
\hline & $\begin{array}{l}\text { The cognitions of development of online } \\
\text { entrepreneurship }\end{array}$ & $64.50^{* * *}$ & $25.49 * * *$ \\
\cline { 2 - 4 } $\begin{array}{l}\text { Influencing } \\
\text { factors }\end{array}$ & $\begin{array}{l}\text { The cognitions of online entrepreneurial } \\
\text { platform convenience }\end{array}$ & $62.33^{* * *}$ & $21.74 * * *$ \\
\hline & $\begin{array}{l}\text { The cognitions of social of online } \\
\text { entrepreneurship }\end{array}$ & $63.17^{* * *}$ & $36.69 * * *$ \\
\hline
\end{tabular}

In order to further understand the results of the questionnaire, this paper explores the impact of gender, age, major, entrepreneurial time and used online entrepreneurial platform on online entrepreneurial behavior and its influencing factors. This paper organizes an independent-samples T-test of individual variables (gender, age, major, entrepreneurial time) on online entrepreneurial behavior and its influencing factors and the results are not shown here. Our results indicate that gender, age, major, and entrepreneurial time have a significant impact on online entrepreneurial behavior. For example, the monthly operating cost of female online entrepreneurs is significantly more than that of men, with a total of RMB 1,679.84. And female online entrepreneurs earn more than monthly revenue. RMB 7,203.22. The monthly operating cost of online entrepreneurs over 23 years old is significantly RMB 3,607.95 more than that of under 22 years old. And the monthly revenue of online entrepreneurs over 23 years old is significantly RMB 8,804.91 more than that of under 22 years old. The monthly operating cost of non-management online startups is significantly higher than that of the management category, which is RMB 2,796.27. The monthly revenue of non-management online startups is significantly RMB 7,045.5 more than that of management categories. What's more, the longer the entrepreneurial time, the higher the online entrepreneurship cost.

For example, the approval degree of women's with the cognitions on the convenience of online entrepreneurial platform, the development and social of online entrepreneurship is significantly higher than that of men. For example, the cognitions on the advantages of online entrepreneurship of entrepreneurs under the age of 22 is significantly lower than that of over 23 . And the approval degree on the cognitions of online entrepreneurial platform convenience, the cognitions on development and social of online entrepreneurship of those over 23 years old is significantly higher than that of under 22. For example, the approval degree on the cognitions of online entrepreneurship's advantages by those majored in management is significantly lower than those majored in non-management. What's more, the approval degree on the cognitions of online entrepreneurial platform convenience, online entrepreneurship's development and social by those majored in non-management is significantly higher than that of those majored in management.

For example, the online startups of Taobao's online entrepreneurs have a RMB8864.34 and a RMB5131.58 higher operating costs and benefits per month than other entrepreneurs. The monthly revenue and operating costs of online entrepreneurs who use the online entrepreneurial platforms such as Paipai, eBay, and self-built websites are significantly lower. And online entrepreneurs who choose Taobao as their entrepreneurial platform has a higher approval degree on the cognitions of online entrepreneurial platform convenience, the development and social of online entrepreneurship than the other, but their the approval degree on the cognitions of online entrepreneurship's advantages is significantly lower. Online entrepreneurs who choose Paipai, eBay, and self-built websites are on the opposite in the above situations.

Based on the above discussion, this paper suggests: 1 . Online entrepreneurs should strengthen financial management knowledge and skills, and pay attention to the interpretation and improvement 
of financial statement analysis. As listed in this paper, the average monthly cost of online entrepreneurs does not reach RMB 10,000. According to the interview results, the reason is that the respondents lack financial management knowledge and skills, so the online start-up costs are underestimated and the control is insufficient. If online entrepreneurs want to continue to develop their business, they need to strengthen their knowledge of financial management and financial statements.

2. The online entrepreneurial rate of return is high, but so is the risk. Therefore, so many governments provide legal protection. Online entrepreneurs should understand the relevant laws and regulations and cooperate as soon as possible to protect their own rights and interests. For example, Article 4 of the "Notice on Launching Online Entrepreneurship Work" implemented by the Ningbo Municipal Government of China on February 1, 2016 stipulates that online entrepreneurs may apply for secured loan interest subsidies and social insurance subsidies.

3. According to the survey results of this paper, the online entrepreneurs' approval degree on the cognitions of online entrepreneurship's advantages and social and online entrepreneurial platform convenience is higher than $73 \%$. Therefore, the government should increase the public's willingness to start an online entrepreneurship through policy promotion and platform promotion. For example, Zhenhai District Government of Ningbo City issued the "Opinions on the Supporting Policies for Online Entrepreneurship in Zhenhai District” on April 28, 2014. The policy encourages people to rely on professional online entrepreneurship platforms to start businesses through venue rental subsidies, financial contribution incentives, financial support incentives, talent training subsidies, improved supporting services, sound entrepreneurial service platforms, network startup enterprise associations, and enhanced service guarantees.

4. The government's online entrepreneurial policies should be varied by the gender, age, major, and entrepreneurial time of online entrepreneurs. According to the statistical results of this paper, online entrepreneurial behaviors and its influencing factors will be different due to personality variables, so the government's online entrepreneurial policy should be differentiated according to individual variables.

5. Online entrepreneurs should build their brand image. This paper finds that behaviors of entrepreneurs who choose Taobao as their entrepreneurial platform is different from that of others. And this paper believes that the supporting measures and platform image of other online entrepreneurial platforms need to be strengthened.

\section{Conclusion}

With the continuous increase in the number of online users and the popularity of online entrepreneurial platforms in China, online entrepreneurship has become one of the best choices for Chinese entrepreneurs. Online entrepreneurship has gradually become a common entrepreneurial model. And more and more governments, enterprises and scholars conduct relevant research. The purpose of this paper is to explore online entrepreneurial behavior and its influencing factors, and to analyze the impact of gender, age, major, entrepreneurial time, and platform.

According to the statistics of the questionnaire, it is found that: 1 . The monthly cost of Chinese people's online entrepreneurship is about RMB 9,000, the monthly revenue is about RMB 18,000, and the revenue is more than double the cost. Therefore, online entrepreneurship should be the entrepreneurial channel adopted by the Chinese people. 2. The cognitions on the conveniences of online entrepreneurial platform, and the advantages, development and social of online entrepreneurship are significant factors influencing online entrepreneurial behavior. Therefore, the government and online entrepreneurial platform should issue policies which consider the influencing factors of online entrepreneurial behavior and improve the entrepreneurial service platform. 3 . The gender, age, major, entrepreneurial time, and used online entrepreneurial platforms of entrepreneur have the significant impacts on online entrepreneurial behavior. Industry, government, and scholars should develop policies and research topics separated with different individual variables. Further research directions in this paper include the impact of regional and national policies on online 
entrepreneurial behavior and its influencing factors. For example, Huang (2013) found that geography will affect online entrepreneurial behavior. Moreover, Liu Xinren (2016) emphasizes the impact of national policies on online entrepreneurial behavior.

\section{References}

[1] Netease Cloud, ITJUZI, 2017 Internet Entrepreneur Group Survey Report, 2017.

[2] Guangdong Provincial Government, Guangdong Province "Internet +" Action Plan (2015-2020), 2015.

[3] Qu, J, Zhang, C, Shi, Y, The Influence of Online Entrepreneurship Education on College Students' Early Online Entrepreneurial Behavior, Science-Technology and Management, 2015,17(06):108-114.

[4] Australian APEC Study Centre, Digital Entrepreneurship Across the APEC Region Assessing the Needs of the Regions Digital Start-ups, 2017.

[5] Ministry of Information and Communication Technology, Country Progress Report, Paper presented at 23rd meeting and conference, Hanoi, Vietnam, Thailand: Asia Pacific Council for Trade Facilitation and Electronic Business.

[6] Zhang, Y, Zhang, J, Zhang, B. The Status Quo, Problems and Countermeasures of College Students' Online Entrepreneurship, Success (Education Version), 2012(02):37-38.

[7] He, X., Problems and Countermeasures of College Students' Online Entrepreneurship in the Information Age, E-education Research, 2011(04):39-41.

[8] Zhou, C., Zhang, M., Investigation and Analysis of College Students' Online Entrepreneurship Based on "Network +", Shanxi Science and Technology, 2017,33(02):11-15.

[9] Zhou, X., Wu, Y., Research on College Students' Online Entrepreneurship Model Based on Campus E-commerce, Coastal Enterprises and Science \& Technology, 2011(10):107-110.

[10]China e-Business Research Centre, 2012.

[11]Liu, H., Xing, Y., College Students' Online Entrepreneurship Based on SWOT Analysis, Education and Vocation, 2014(20):104-105.

[12]China e-Business Research Centre, 2017.

[13]Qiu, H., Research on Students' Online Entrepreneurship in Higher Vocational Colleges__ Taking the Operation of Youth Network Company of Guangzhou Civil Aviation Vocational and Technical College as an Example, Vocational Education Research, 2014(10):72-76.

[14]Baum, J., Locke, E. A., Smith, K. G.. A multidimensional Model of Venture Growth, Academic Management Journal, 44(2):292-304.

[15]Xiao, J., Chen, L., Research on the Current Situation and Countermeasures of College Students' Internet Entrepreneurship, China University Students Career Guide, 2013(20):56-60.

[16]Zhang, X., Ma, Y., Promoting China's Online Entrepreneurship and Employment, China Labour, 2013(06):4-10.

[17]Hu, G., Mao, C., Wang, J., Some Rational Thoughts on College Students' Response to College Students' Online Entrepreneurship, Technoeconomics \& Management Research, 2010(05):103-106.

[18]Huang, W., College Students' Online Entrepreneurship in West China, Chongqing Social Sciences, 2013(07):46-52. 